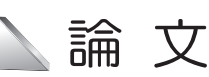

Original Paper

\section{ロータリ・パーカッション掘削における 岩石掘削特性に関する研究 *}

唐 澤 廣 和 $^{1}$ 鈴 木 宏 治 $^{2}$ 高 橋 幸 司 $^{3}$

\title{
Rock Drillability in Rotary-Percussion Drilling
}

\author{
by Hirokazu KARASAWA ${ }^{\mathrm{a}}$, Koji SUZUKI ${ }^{\mathrm{b}}$ and Koji TAKAHASHI ${ }^{\mathrm{b}}$
}

a. National Institute of Advanced Industrial Science and Technology (AIST), Institute for GeoResources and Environment, 16-1 Onogawa, Tsukuba, Ibaraki 305-8569, Japan

(Corresponding author E-mail: karasawa.h@aist.go.jp)

b. Koken Boring Machine Co., Ltd., 2-17-22 Takada, Toshima-ku, Tokyo 171-8572, Japan

There are fewer basic data with respect to percussion drilling than those of rotary drilling, because the measurement of data such as percussion energy is difficult for percussion drilling. These basic data are necessary to implement percussion drilling and to design percussion drills.

A calibration curve between the input energy into the percussion drill and the percussion energy was first made to estimate the percussion energy from the input energy while drilling. Next rotary-percussion drilling and rotary drilling were conducted using a roller cone bit with $4 \mathrm{in}$. diameter. Rocks used for the tests are Sori granite, Shinkomatsu andesite and Sanjome andesite whose uniaxial compressive strength is 223,184 and $100 \mathrm{MPa}$, respectively.

Analyses of drilling data revealed that the minimum value of the specific energy roughly coincides with the uniaxial compressive strength of each rock for both drilling methods. It was also revealed that variation of the specific energy with the bit weight in rotary-percussion drilling is small when compared to rotary drilling. In addition, the penetration rate and the rotary energy of rotary drilling which composes rotary-percussion drilling were estimated to be roughly equal to those of pure rotary drilling.

KEY WORDS: Percussion, Rotary, Roller Cone Bit, Drilling Energy, Specific Energy

1. は じめに

パーカッション ( 打撃) 掘削はロータリ (回転) 掘削に比べて 掘削速度が極めて大きく, 掘削コストや工期の大幅な削減が期待 できる坑井の掘削方式である。実際に, 鉱山や土木分野において 採用されている油圧削岩機 (パーカッション掘削機) によって花 崗岩を掘削した場合, 掘削速度は $50 \sim 100 \mathrm{~cm} / \mathrm{min}$ 程度に達する ${ }^{1)}$ と報告されている。

ロータリ掘削に関しては現在までに無数の研究が行われ，掘削 工具の開発・改良や岩石の掘削特性の解明などに貢献してきてい る。一方, 大久保ら ${ }^{2)}$ はパーカッション掘削に関しては永年の 研究にもかかわらず，未だ不明の点も多く残っていると述べてい る。この一因として, パーカッション掘削機に関わる測定・計測

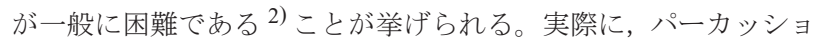
ン掘削の場合は岩石破壊の原動力となるパラメータ ( 打撃力や打

*2008 年 6 月 16 日受付 10 月 28 日受理

資源・素材学会平成 20 年度春季大会にて一部発表

1. 普通会員 工博 (独) 産業技術総合研究所 地圈資源環境研究部門 主 任研究員

2. 鉱研工業 (株) 設計本部 副本部長

3. 鉱研工業 (株) 国内営業本部 係長

[ 著者連絡先 ] FAX: 029-861-8738 E-mail: karasawa.h@aist.go.jp

キーワード: パーカッション，ロータリ，ローラコーンビット，掘削エネ ルギー，比エネルギー
撃エネルギー)の計測自体が困難である。ロータリ掘削ではトル クなどから求めた掘削エネルギーに関わるパラメータ（比エネル ギー ${ }^{3)}$ ) が岩石の掘削特性の解明や岩石強度の評価などに大いに 貢献していることからわかるように, パーカッション掘削におけ る打撃エネルギーの評価も極めて重要であることが容易に推察で きる。

本研究ではパーカッション掘削機への入力エネルギーから打撃 エネルギーを推定する方法を検討するとともに，ローラコーン ビットを用いて硬質な花崗岩および安山岩と, 中硬質の安山岩に 対してロータリ掘削とパーカッション掘削を行い, 特に掘削エネ ルギーに関わる観点から岩石の掘削特性を評価した。

\section{2. 本研究の背景}

上記の油圧削岩機はトップハンマと呼ばれ，地表において発生 させた打撃力がロッドを介してビットに伝えられて掘削を行う装 置である。打撃力はロッド内を伝わる間に減衰するため, 本装置 による掘削可能な深度は $50 \sim 150 \mathrm{~m}$ 程度で, 深い坑井の掘削に は適用できない。また, 前述のとおり, パーカッション掘削は掘 削分野における古くからの課題である能率向上とコス卜削減を達 成する可能性のある技術の一つであるため, 一般に深度数千 $\mathrm{m}$ に達する石油井などの掘削にこの方式を適用しようとする試みは 当然の発想である。 


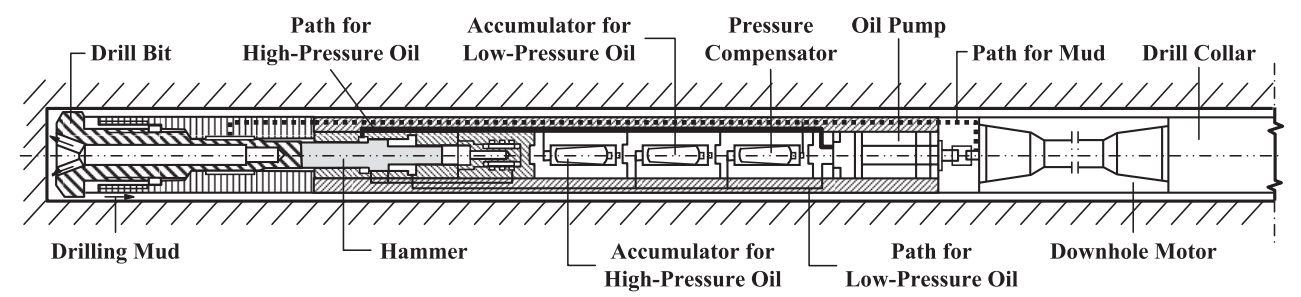

Fig.1 Concept of new downhole percussion drill.

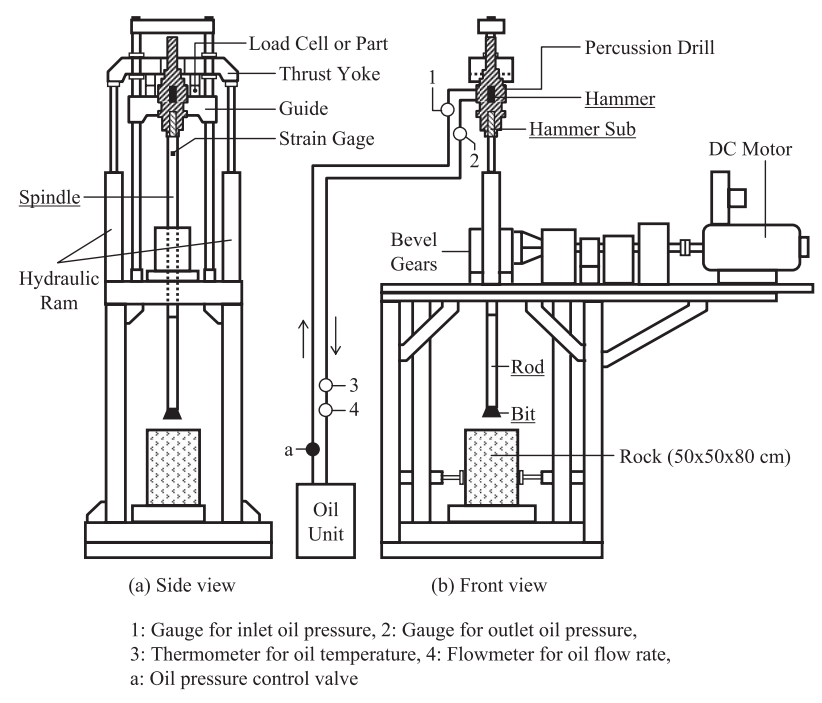

Fig.2 Drilling machine used for tests.

このため, 米国の石油産業は掘削泥水で作動する坑底駆動型の パーカッション掘削機の研究開発を古くから行ってきている ${ }^{4,5)}$ 。 しかし, これらの掘削機では潤滑性が低く, かつ研摩性が著しい 泥水を利用してハンマを直接作動させるため, 部品の急速摩耗な どの問題を克服できず，現在でも実用化に至っていない。このよ うな問題を解決するため, 筆者ら ${ }^{6)}$ は泥水を動力源とし, パーカッ ション機構を潤滑性の高い油で作動させる新しい坑底駆動型の パーカッション掘削機を提案した (Fig. 1)。

実用的な本掘削機の開発のためにはパーカッション機構の出力 などの設計が重要であるものの, パーカッション掘削に関しては 基礎データが少なく適切な設計が困難なため, 本掘削法に関わる 基礎データを収集する目的で本研究に着手した。パーカッション 掘削用のビットとしてはボタンビットなどのパーカッションビッ トとローラコーンビットが挙げられるが，本研究では実験に手慣 れているローラコーンビットを選択した。本ビットによるパー カッション掘削ではビットの構造上，岩石の破壊はロータリ掘削 とパーカッション掘削の両方式によって行われる。後述の 5 章の 考察において用語の混乱を避けるため, この方式をロータリ・パー カッション掘削と呼ぶことにする。

\section{3. 試験装置, 計測方法および掘削実験方法}

\section{$3 \cdot 1$ 試験装置}

Fig. 2 は，打撃エネルギーの推定方法の検討および岩石の掘削 実験に用いた掘削試験装置である。本装置はロータリ掘削機に小 型のパーカッション掘削機を付加したもので, 掘削方式として ロータリ掘削とパーカッション掘削のいずれかを選ぶことができ る。ロータリ掘削機やパーカッション掘削機自体はよく知られた 機械であるため，以下では試験装置の要点のみを説明する。

パーカッション掘削機本体一ガイド，スラストヨークー油圧ラム

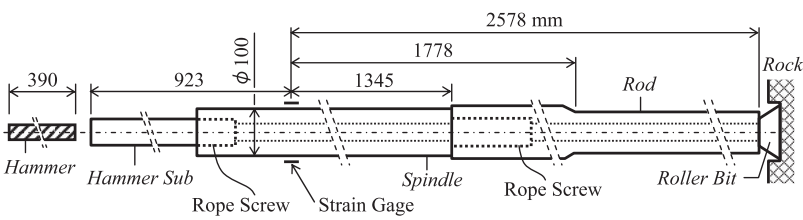

Fig.3 Transfer system for bit weight, percussion force and rotation.

はそれぞれ一体構造となっており，両構造体はロードセルあるい は部材を介して接触する。パーカッション掘削機本体には Fig. 3 に示寸力の伝達系が取り付けられているとともに，伝達系を構成 するスピンドルには回転の伝達機構も設けられているため, ビッ 卜に荷重，打撃力および回転を与えることができる。掘屑を排除 するための掘削流体はパーカッション掘削機本体とハンマサブに 取り付けられたスイベルから送られる。上記ロードセルに代わる 部材は打撃力によるロードセルの破損を防ぐためのもので, ビッ 卜荷重の計測はできない。このため, パーカッション掘削時には 油圧ラム内の油圧を利用して荷重を測定した (以下，この荷重を 油圧荷重と呼ぶ）。

\section{$3 \cdot 2$ 計測方法}

Fig. 3 に示したように，打撃エネルギーを求めるためのひずみ の計測は，スピンドル上方に貼付したひずみゲージ(ゲージ長 $2 \mathrm{~mm}$ ) を4アクティブゲージ法 (直交配置法) にて結線して行っ た。ひずみゲージの出力信号は，シグナルコンディショナ (最大 応答周波数 $500 \mathrm{kHz}$ ) と $\mathrm{A} / \mathrm{D}$ コンバータ ( 分解能 12bit) を介してコ ンピュータに取り込んだ（サンプリング周波数 $1 \mathrm{MHz}$ ，計測時間 2s)。

パーカッション掘削機への入力エネルギーの計測システムは, 上記打撃エネルギーの計測システムとは異なるものである。 Fig. 2 に示したパーカッション掘削機の作動油に関連する測定セ ンサ $(1 \sim 4)$ と, 油圧荷重の測定センサによって得られたデータ

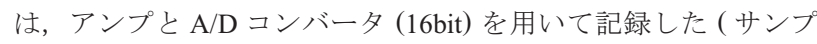
リング周波数 $100 \mathrm{~Hz}$ ，計測時間 $4 \mathrm{~s})$ 。この $4 \mathrm{~s}$ の計測時間内に，上 記ひずみの計測時間 $2 \mathrm{~s}$ が入るように同期させた。

実際の計測は以下のようにして行った (Fig. 3)。ハンマによる 打撃時に伝達系を安定させるため, 先ず直径が 4in. (101.6mm)の ローラコーンビットを用いて沢入花崗岩 (一軸圧縮強度 : 約 $190 \mathrm{MPa}$ ) に深さ数十 $\mathrm{mm}$ の孔を掘削し，この孔内にビットを挿入 した。実験上の都合から，打撃エネルギーの計測は，約 $9 \mathrm{kN} の$ 油圧荷重を加えた状態で伝達系を回転せずに静止させて行った。 ただし，伝達系の 2 ケ所のロープねじが打撃時に緩まないように 緩み止めを施した。Fig. 2 に示した油圧制御弁 a 用いてパーカッ ション掘削機の入口油圧を変化させて, 入力エネルギーと打撃エ ネルギーを計測した。なお, これらデータの值は油温度によって も変化するため, 所定の条件におけるデータの計測では, 油温度 がほぼ一定となるように留意した (計測時間 $4 \mathrm{~s}$ における油温度 の変化は $0.2^{\circ} \mathrm{C}$ 以内であった)。 


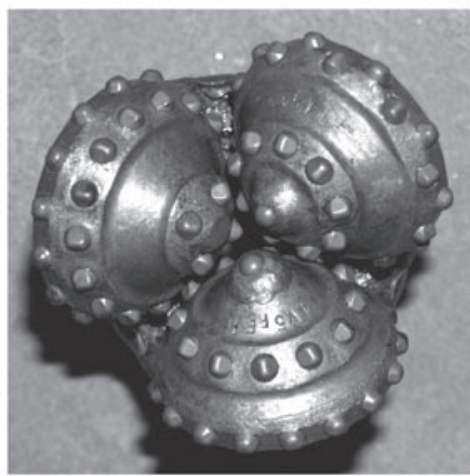

Fig.4 Roller cone bit with 4 in. diameter used for tests (IADC: 627X).

Table 1 Mechanical properties of rocks used for drilling tests.

\begin{tabular}{lccccc}
\hline \multicolumn{1}{c}{ Rock } & $S_{c}(\mathrm{MPa})$ & $S_{t}(\mathrm{MPa})$ & $E(\mathrm{GPa})$ & $v$ & $S H$ \\
\hline Sori granite & 223 & 10.3 & 59.9 & 0.302 & 99.3 \\
\hline Shinkomatsu andesite & 184 & 9.34 & 23.8 & 0.354 & 79.0 \\
\hline Sanjome andesite & 100 & 8.39 & 12.7 & 0.246 & 61.6 \\
\hline
\end{tabular}

$S_{c}$ : Uniaxial Compressive Strength, $S_{t}$ : Tensile Strength, $E$ : Young's Modulus, $v:$ Poisson's Ratio, $S H$ : Shore Hardness

Table 2 Drilling conditions for each rock type.

\begin{tabular}{llccc}
\hline \multicolumn{1}{c}{ Rock } & Method & $N(\mathrm{rpm})$ & $F(\mathrm{kN})$ & $P_{\text {in }}(\mathrm{MPa})$ \\
\hline Sori Granite & Rotary & 25 & $10-70$ & - \\
& Percussion & 25 & $10-70$ & $7.6-13.1$ \\
\cline { 2 - 5 } & Rotary & 50 & $10-70$ & - \\
& Percussion & 50 & $10-70$ & $9.4,13.2$ \\
\hline Shinkomatsu & Rotary & 25 & $10-70$ & - \\
Andesite & Percussion & 25 & $10-70$ & $7.7-13.2$ \\
\hline Sanjome & Rotary & 25 & $10-40$ & - \\
Andesite & Percussion & 25 & $10-40$ & $7.6,10.3$ \\
\hline$N:$ Rotary Speed, $F:$ Bit Weight, $P_{\text {in }}:$ Inlet Oil Pressure &
\end{tabular}

\section{3 - 3 掘削実験方法}

打撃エネルギーの計測や岩石の掘削実験に用いたビットは, WC-Co 製のチゼルインサートを刃先とする直径が 4in. のローラ コーンビットである (Fig. 4)。本ビットによる掘削実験に用いた 岩石は沢入花崗岩, 新小松安山岩および三城目安山岩で, これら 岩石の機械的性質をTable 1 に示す。

予備実験として，本ビットを用いて沢入花崗岩をロータリ掘削 (ビット回転数 $50 \mathrm{rpm}$ ，清水流量 $110 \mathrm{~L} / \mathrm{min}$ ) した結果，掘削速度 が $10 \mathrm{~cm} / \mathrm{min}$ 程度になると掘削流体による掘屑の排除が不十分と なり，掘削速度に影響を与える場合があることがわかった。パー カッション掘削を行うと，さらに掘削速度が増大して掘屑の排除 がより困難になって掘削速度に悪影響を与えることが予想された ため, 主要な掘削実験はビット回転数を $25 \mathrm{rpm}$ 一定にして行った。 Table 2 に各岩石の主な実験条件を記載した。表からわかるよう に，沢入花崗岩についてはビット回転数が $50 \mathrm{rpm}$ の掘削実験も 行った。いずれの実験においても掘削流体は清水で，流量は $110 \mathrm{~L} / \mathrm{min}$ 一定とした。

前記のようにパーカッション掘削の場合は油圧荷重のみを計測 したが，本荷重はヒステリシス現象を示すためロードセルで測定 した荷重 (ロードセル荷重) とは多少異なる。そこで，ロータリ 掘削時にロードセル荷重と油圧荷重の両者を測定し，その結果を 基にパーカッション掘削時に測定した油圧荷重をロードセル荷重 に補正した。したがって，本論文の掘削実験結果に示すビット荷

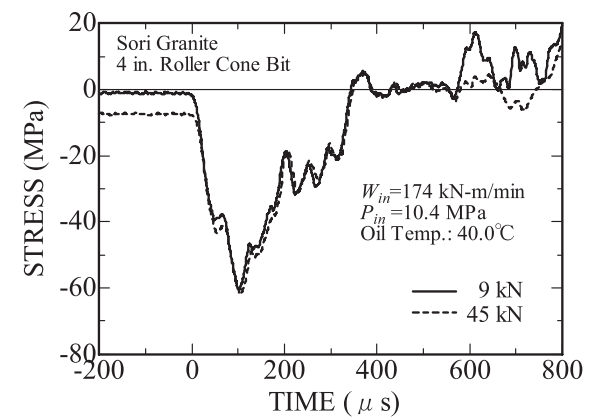

Fig.5 Effect of load measured by hydraulic ram on stress.

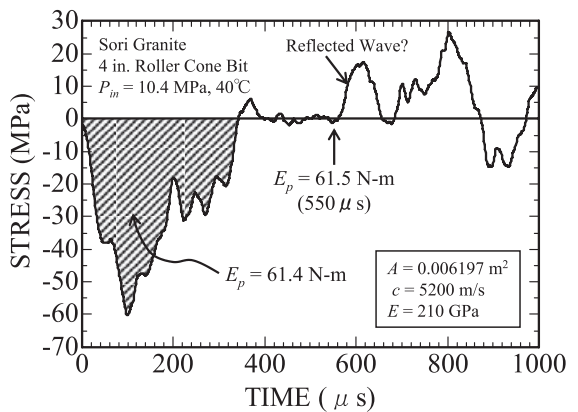

Fig.6 An example of relationship between time and stress.

重 $F$ はロードセル荷重を表している ( 油圧荷重を用いる場合は明 記する )。

\section{4. 打撃エネルギーの推定方法}

\section{$4 \cdot 1$ 油圧荷重が応力波形に及ぼす影響}

ローラコーンビットによる岩石の掘削では，一般に直径 1 in. 当 り 10 〜 $20 \mathrm{kN}$ 程度の荷重が推奨されている。このように静的な荷 重が加わった状態で打撃力が作用した場合の打撃エネルギーの評 価法については明確になっていない。そこで，油圧荷重を約 9, $16 ， 26 ， 45 \mathrm{kN}$ と変化させて時間と応力との関係を調べた (Fig. 5)。 図の繁雑さを避けるため, 図には油圧荷重が約 $9 \mathrm{kN}$ と $45 \mathrm{kN}$ のデー タのみを示した (応力は圧縮が負)。応力波形の立ち上がり部を 除いていずれの波形も概ね一致しており，また，図中に記載した ように油圧荷重以外のデータ（後述のパーカッション掘削機への 一分間当りの入力エネルギー $W_{i n}$, 入口油圧 $P_{i n}$, 油温度 ) もほぼ 一定であった。このように，応力波形に及ぼす静的な荷重の影響 は小さいことから，以下に述べる打撃エネルギーの計算では応力 值 0 を起点として選んだ。

図からわかるように，波形の立ち上がり以前の両データの応力 差はそれ以後ではほとんど消滅している。これは，ハンマの打撃 によって生ずるスピンドルの急激な圧縮に対して油圧ラムの下降 が瞬間的に追従できず，静的な荷重を載荷できなくなったためと 考えられる。図示されていないが，波形立ち上がりから約 $0.01 \mathrm{~s}$ 後には静的な応力差を含む両波形が観察された。

\section{$4 \cdot 2$ 打撃エネルギ一の推定方法}

Fig. 6 に，打撃エネルギーを求めるために計測したデータの一 例を示す。ハンマの一打撃当りの打撃エネルギー $E_{p}(\mathrm{~N} \cdot \mathrm{m})$ は次 式によって求めた 7)。

$$
E_{p}=\frac{A c}{E} \int_{t_{1}}^{t_{2}} \sigma^{2} d t
$$

ここで，A はスピンドル断面積 $\left(\mathrm{m}^{2}\right), c$ は弾性波速度 $(\mathrm{m} / \mathrm{s}), E$ は 
Table 3 Values of parameters to calculate percussion energy at spindle

\begin{tabular}{ll}
\hline Cross-Sectional Area $A$ & $0.006197 \mathrm{~m}^{2}$ \\
\hline Elastic Wave Speed $c^{*}$ & $5200 \mathrm{~m} / \mathrm{s}$ \\
\hline Young's Modulus $E^{*}$ & $210 \mathrm{GPa}$ \\
\hline$*$ Measured Values &
\end{tabular}

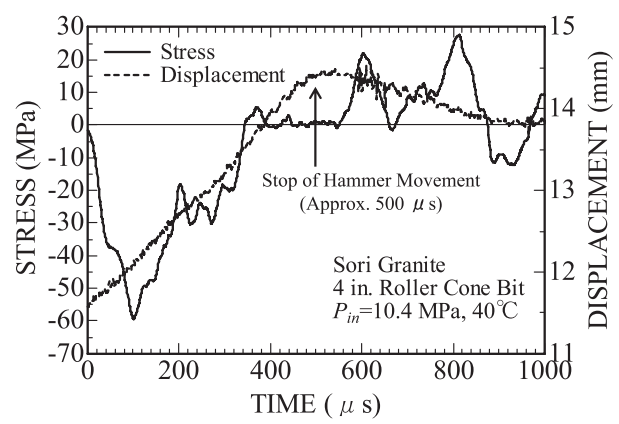

Fig.7 Stress-time and hammer displacement-time relationships.

ヤング率 $(\mathrm{GPa}), \sigma$ は応力 $(\mathrm{MPa}), t$ は時間 $(\mu \mathrm{s})$ である。具体的 には, Fig.6 に示寸最初の圧縮応力波 (斜線部, 0 ～約 $340 \mu \mathrm{s}$ ) に ついて $E_{p}$ を求めた。スピンドルの $A, c, E$ を Table 3 に示す。

$E_{p}$ の計算範囲を斜線部としたのは, ハンマの一打撃当りの打 撃エネルギーの大部分がこの部分に含まれているためである。 Fig. 7 は，ひずみゲージとレーザ変位計を用いて同時に計測した 時間と応力, 時間とハンマ変位 (往復運動方向) との関係の一例 である。ハンマがハンマサブを打撃して生じた弾性波がひずみ ゲージに到達するまでの時間 $(178 \mu \mathrm{s})$ は補正してあるので, 両者 に時間のずれはない。油圧荷重が約 $9 \mathrm{kN}$, 入口油圧 $P_{i n}$ を 8.5 , $10.4,12.3 \mathrm{MPa}$ で変化させたデータ (各条件 3 個) を解析したと ころ, 大部分のデータにおいて約 $500 \sim 550 \mu \mathrm{s}$ でハンマの変位 がほぼ一定となり運動が停止することがわかった。このため, Fig. 6 に示すように0〜550 $\mu$ s までの $E_{p}$ を計算したところ, 斜 線部の $E_{p}$ とほとんど変わらなかった。この結果を基に, $E_{p}$ の計 算範囲を上記のように定めた。

弾性波速度を考慮すると， $600 \mu \mathrm{s}$ 付近の引張応力波はスピンド ルとロッドの継手部からの反射波であると推定される (Fig. 6)。 大久保ら ${ }^{8)}$ は，弾性波がスリーブ式のロッド継手一つを通過す るときに弾性波 (打撃) エネルギーが約 $3 \%$ 減衰すると報告して いる。この研究と本研究の場合は継手の構造などが異なるため, この減衰率を適用することは妥当でないと考えるものの, この程 度の打撃エネルギーの減衰は十分あり得ると推察される。本研究 では，スピンドルとロッドの継手部における打撃エネルギーの減 衰については考慮せず, 斜線部の打撃エネルギー $E_{p}$ がビットに 伝達すると仮定した。なお，Fig. 2 に示したベベルギアの回転の スピンドルへの伝達は, スピンドルに設けられたキー溝とベベル ギアに固定されたキーとによって行われる。キーとキー溝は油に よって潤滑されており, スピンドルは円滑に上下動できるように なっているため, 測定された応力波形に及ぼす回転伝達機構の影 響はほとんどないか，小さいと考えられる。

パーカッション掘削機への一分間当りの入力エネルギー $W_{i n}$ $(\mathrm{kN} \cdot \mathrm{m} / \mathrm{min})$ と一分間当りの打撃エネルギー $W_{\text {out }}(\mathrm{kN} \cdot \mathrm{m} / \mathrm{min})$ は それぞれ次式から求めた。

$$
\begin{aligned}
& W_{\text {in }}=Q\left(P_{\text {in }}-P_{\text {out }}\right) \cdots \cdots \\
& W_{\text {out }}=\frac{E_{p-a v e} \times f \times 60}{1000}
\end{aligned}
$$

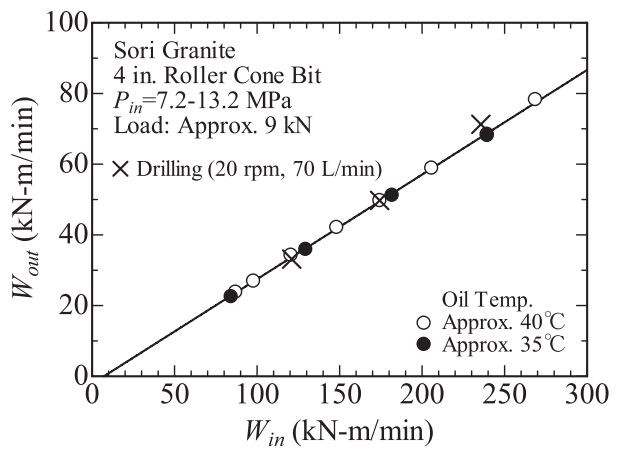

Fig.8 Relationship between input energy per minute $W_{\text {in }}$ and percussion energy per minute $W_{\text {out }}$.

Table 4 Effect of load on percussion energy $\left(E_{p \text {-ave }}\right)$.

\begin{tabular}{ccc}
\hline Load* $(\mathrm{kN})$ & $E_{p \text {-ave }}(\mathrm{N} \cdot \mathrm{m})$ & Increment $(\%)$ \\
\hline 9 & 62.0 & 0 \\
\hline 16 & 62.9 & 1.5 \\
\hline 26 & 63.7 & 2.7 \\
\hline 45 & 67.7 & 9.2 \\
\hline
\end{tabular}

* Measured by Hydraulic Ram

ここで, $Q$ は油流量 $(\mathrm{L} / \mathrm{min}), P_{\text {in }}$ は入口油圧 $(\mathrm{MPa}), P_{\text {out }}$ は出口 油圧 $(\mathrm{MPa}), E_{p \text {-ave }}$ は個の $E_{p}$ の平均值 $(\mathrm{N} \cdot \mathrm{m}), f$ は打撃周波 数 $(\mathrm{Hz})$ である。 3 個の $E_{p}$ は計測データの序盤, 中盤, 終盤から 選んで求めたものである。

Fig. 8 に，一分間当りの入力エネルギー $W_{i n}$ と一分間当りの打 撃エネルギー $W_{\text {out }}$ との関係を示す。図中の直線は油温度が約 $40^{\circ} \mathrm{C}$ と $35^{\circ} \mathrm{C}$ のデータを最小二乗法による近似から求めたもので ある ( 入口油圧 $P_{i n}$ の範囲は 7.2 13.2MPa)。前記のように両デー タはビットを回転しないで計測した。そこで, 本データの妥当性 を確認するため, ビット回転数が $20 \mathrm{rpm}$, 油圧荷重が約 $9 \mathrm{kN}$ で 沢入花崗岩を掘削して $W_{\text {in }}$ と $W_{\text {out }}$ を計測した。図に示したように, これらのデータ ( X印) は直線とほぼ一致していることから, 掘 削実験時の打撃エネルギー $W_{\text {out }}$ は入力エネルギー $W_{\text {in }}$ から推定 できることがわかった。図から明らかなように，少なくとも油温 度が約 $35^{\circ} \mathrm{C}$ 以上であればハンマは円滑に作動して打撃エネル ギー $W_{\text {out }}$ の推定に問題がないことがわかったため, パーカッショ ン掘削による岩石の掘削実験は油温度が $40^{\circ} \mathrm{C}$ 程度で実施するこ ととした。なお, Fig. 8 に示した油温度が約 $40^{\circ} \mathrm{C}$ のデータの場合, 一分間当りの打撃数は入力エネルギーの増加につれて 601 から 992 (blows/min) まで増大した。

前記のように, Fig. 8 に示したデータは油圧荷重が約 $9 \mathrm{kN}$ のと きのものである。Fig. 5 に示した油圧荷重の異なるデータについ て打撃エネルギー $E_{p \text {-ave }}$ を求めた結果を Table 4 に示す。表から, 油圧荷重が $45 \mathrm{kN}$ の $E_{p \text {-ave }}$ は $9 \mathrm{kN}$ と比較して約 $9 \%$ 増大している ことがわかる。一方, Fig. 5 の両荷重データにおいて, 継手部か らの反射波と推定される $600 \mu \mathrm{s}$ 付近の応力波に相違が見られる。 このように, 静的な応力が衝撃的な応力に及ぼす影響については 不明の点も残っており，さらに検討の余地があると考える。この ため，本論文では油圧荷重が約 $9 \mathrm{kN}$ のときに得られた校正デー タ (Fig. 8) によって掘削実験時の打撃エネルギーを推定した。

\section{5. 掘削実験結果と考察}

\section{$5 \cdot 1$ 油温度が入カエネルギー $W_{i n}$ に及ぼす影響}

掘削実験中の入力エネルギー $W_{i n}$ の計測時間は Fig. 8 に示した 


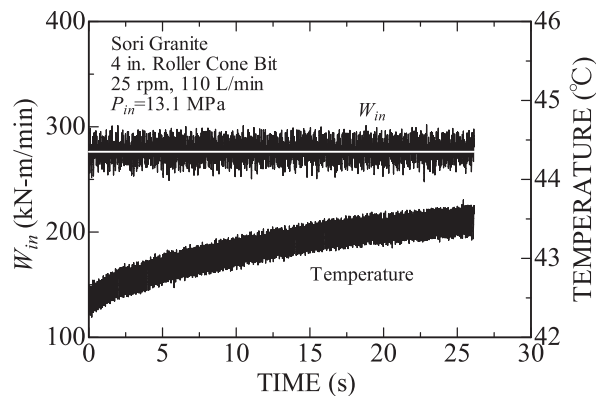

Fig.9 Effect of variation of oil temperature on $W_{i n}$.

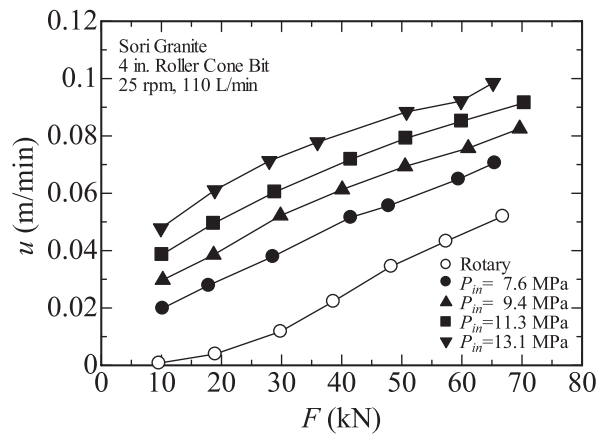

Fig.10 Relationship between bit weight $F$ and penetration rate $u$ in drilling Sori granite at $25 \mathrm{rpm}$.

$W_{\text {in }}$ の計測時間 $4 \mathrm{~s}$ に比べて長くなるため, 一般に油温度の変化も 大きくなる。すべてのロータリ・パーカッション掘削による実験

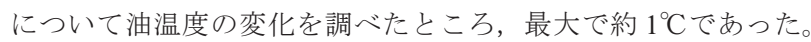
そこで, 油温度が約 $1{ }^{\circ} \mathrm{C}$ 変化したデータの一つについて $W_{\text {in }}$ の変 化状況を調べた (Fig. 9)。図中の $W_{i n}$ はデータ数 5 個の移動平均 処理をしたもので, 白線が平均值である (温度は生データ)。油 温度が約 $1{ }^{\circ} \mathrm{C}$ 変化しても, 時間に伴う $W_{i n}$ の変化は認められない。 したがって, $W_{\text {in }}$ や打撃エネルギー $W_{\text {out }}$ に及ぼす油温度の影響は 小さいと判断される。一方，本実験では例えば後述の Fig. 10 の 入口油圧 $P_{i n}=7.6 \mathrm{MPa}$ の複数のデータについては一連の実験とし て連続的に測定した。上記のように各データについては油温度の 変化が約 $1^{\circ} \mathrm{C}$ 以内に収まったものの, データごとの油温度はそれ 以上に変化した。これら一連のデータにおいて, 油温度の変化に 伴う $W_{\text {in }}$ の変化は最大で $3.6 \%\left(W_{\text {out }}\right.$ で $\left.3.8 \%\right)$ であった。

$5 \cdot 2$ 実験結果

$5 \cdot 2 \cdot 1$ ビット荷重と掘削速度との関係 Fig. 10 は, ビット回転数が $25 \mathrm{rpm}$ で沢入花崗岩をロータリ掘削とロータリ・ パーカッション掘削して得られたビット荷重 $F$ と掘削速度 $u$ と の関係である。図から，入口油圧 $P_{i n}$ にかかわらずビット荷重が 小さい範囲ではロータリ・パーカッション掘削の速度はロータリ 掘削に比べて極めて大きい一方，ビット荷重が大きい範囲では両 者の差はやや小さくなることがわかる。花崗岩のような硬岩の ロータリ掘削においてビット荷重が小さいと, 岩石中に刃先がほ とんど圧入されないため掘削速度が極めて小さくなることは古く から知られており, 本図はそれを如実に示している。従来から報 告されていることであるが, パーカッション掘削の長所の一つと して, 硬質岩掘削時のロータリ方式の問題点を解決できることが 挙げられる。本掘削法の他の長所として孔曲りの減少なども指摘 されている5)。

沢入花崗岩 (ビット回転数 $50 \mathrm{rpm}$ ), 新小松安山岩および三城 目安山岩も, 上記の沢入花崗岩の実験結果と同様な傾向を示した。

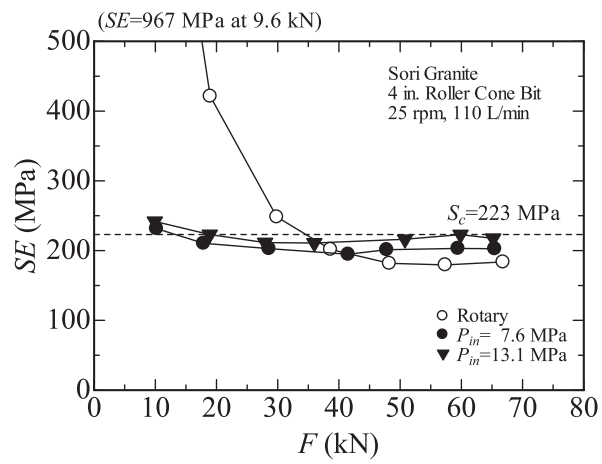

Fig.11 Relationship between $F$ and specific energy $S E$ in drilling Sori granite at $25 \mathrm{rpm}$.

$5 \cdot 2 \cdot 2$ ビット荷重と比エネルギーとの関係ロータリ・ パーカッション掘削とロータリ掘削の特徽を明らかにするために, 掘削エネルギーの観点からデータを解析する。

ロータリ・パーカッション掘削における一分間当りの掘削エネ ルギー $W_{\text {drill }}(\mathrm{kN} \cdot \mathrm{m} / \mathrm{min})$ と, 比エネルギー ( 単位体積の岩石を掘 削するのに要するエネルギー) $S E(\mathrm{MPa})$ として次式を提案する。

$$
\begin{aligned}
& W_{\text {drill }}=F u+2 \pi N T+W_{\text {out }} \\
& S E=\frac{W_{\text {drill }}}{1000 S u} \ldots \ldots \ldots \ldots \ldots \ldots \ldots \ldots
\end{aligned}
$$

ここで, $F$ はビット荷重 $(\mathrm{kN}), u$ は掘削速度 $(\mathrm{m} / \mathrm{min}), N$ はビッ 卜回転数 $(\mathrm{rpm}), T$ はトルク $(\mathrm{kN} \cdot \mathrm{m}), W_{\text {out }}$ は前記の一分間当り の打撃エネルギー $(\mathrm{kN} \cdot \mathrm{m} / \mathrm{min}), S$ は掘削孔の断面積 $\left(\mathrm{m}^{2}\right)$ である。 ロータリ掘削における $W_{\text {drill }}$ や SE は, (4) 式と (5) 式中の $W_{\text {out }}$ を 消去して求めることができる ${ }^{3)}$ 。

Fig. 11 は，ビット回転数が $25 \mathrm{rpm}$ で沢入花崗岩をロータリと ロータリ・パーカッション掘削したときのビット荷重と比エネル ギー $S E$ との関係である。入口油圧 $P_{i n}$ を 4 段階に変化させたロー タリ・パーカッション掘削の比エネルギーは $P_{\text {in }}$ が $7.6 \mathrm{MPa}$ と $13.1 \mathrm{MPa}$ の範囲内にあるため, 他のデータは記載しなかった ( 図 中の破線は岩石の一軸圧縮強度 $S_{c}$ を表している)。比エネルギー の最小值は, ロータリ掘削が $180 \mathrm{MPa}$, ロータリ・パーカッショ ン掘削が 195 〜 $211 \mathrm{MPa}$ である ( 比エネルギーの最小值が持つ工 学的な意味は後述する)。また, 図からロータリ掘削の比エネル ギーはビット荷重の増大につれて急激に小さくなるのに対し, ロータリ・パーカッション掘削の場合はビット荷重に伴う比エネ ルギーの変化が小さい $(195 \sim 242 \mathrm{MPa})$ ことがわかる。ロータリ 掘削において低荷重域の比エネルギーが極端に高いのは前記の岩 石中への刃先の圧入深さが小さい ( 掘削体積が小さい) ことと密 接に関連しており, 比エネルギーの観点からも掘削能率の低さが わかる。一方，ロータリ・パーカッション掘削においてビット荷 重が小さいにもかかわらず比エネルギーが小さいのは, Fig.10か らわかるように打撃力によって岩石中に刃先が圧入されて効率的 な掘削ができているためである。ビット回転数が $50 \mathrm{rpm}$ のとき のビット荷重と比エネルギーとの関係も, 上記回転数が $25 \mathrm{rpm}$ の場合と同様の結果を示した。すなわち，比エネルギーの最小值 は，ロータリ掘削が $185 \mathrm{MPa}$ ，ロータリ・パーカッション掘削が $191 \mathrm{MPa}$ と $195 \mathrm{MPa}$ であった。

Fig. 12 は, 新小松安山岩のビット荷重と比エネルギーとの関 係である。比エネルギーの最小值は, ロータリ掘削が $181 \mathrm{MPa}$, ロー タリ・パーカッション掘削が $187 〜 211 \mathrm{MPa}$ となっている。新小 松安山岩のロータリおよびロータリ・パーカッション掘削の比エ 


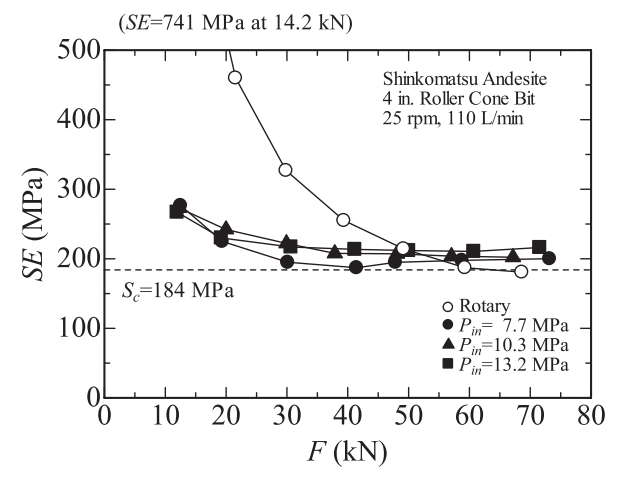

Fig.12 Relationship between $F$ and $S E$ in drilling Shinkomatsu andesite at $25 \mathrm{rpm}$.

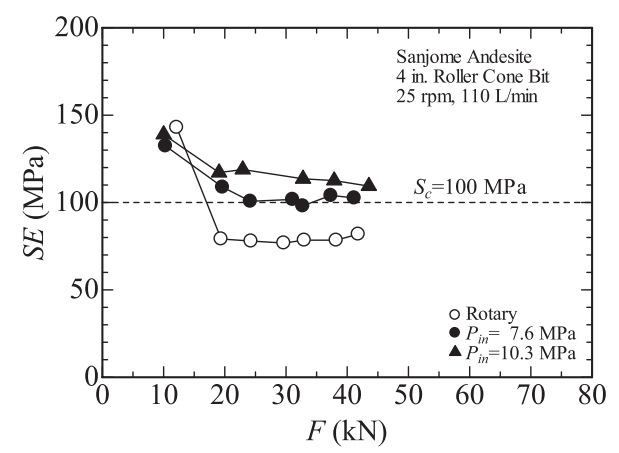

Fig.13 Relationship between $F$ and $S E$ in drilling Sanjome andesite at $25 \mathrm{rpm}$.

ネルギーの変化状況は沢入花崗岩とほぼ同じ傾向を示しており, これらの傾向は上記沢入花崗岩の場合と同様に岩石中への刃先の 圧入深さで説明できる。

Fig. 13 に示寸三城目安山岩のデータから, 比エネルギーの最 小值はロータリ掘削が $77 \mathrm{MPa}$, ロータリ・パーカッション掘削 が 98MPa と 109MPa であることがわかる。また, 三城目安山岩 のロータリ掘削の場合はビット荷重が約 $20 \mathrm{kN}$ 以上になると比エ ネルギーがほぼ一定となっており, 上記沢入花崗岩や新小松安山 岩のロータリ掘削の場合と傾向が異なる。これは, 強度が小さい 三城目安山岩の場合は低荷重でも岩石中に刃先が圧入されやす く，岩石の破壊が効率的に行われているためと考えられる。

$\mathrm{Teale}^{3)}$ は，2，3 の機械的な岩石の掘削法において比エネルギー の最小值が掘削した岩石の一軸圧縮強度と大雑把に一致するとい う工学的に極めて有用な事実を見出した。この事実の有用性は, 例えばローラコーンビットによる坑井掘削の際に原位置における 圧縮強度を測定するため, 比エネルギーの最小值を簡便に求める 方法が提案されていることからもわかる ${ }^{9)}$ 。Fig.11〜13 から明 らかなように，ロータリ掘削とロータリ・パーカッション掘削の いずれにおいても本実験で得られた比エネルギーの最小值は岩石 の一軸圧縮強度と大雑把に一致しており, 彼の報告と矛盾しない 結果が得られた。ただし，実験結果から明らかなように比エネル ギーの最小值はいずれの岩石でもロータリ掘削から得られてい る。大久保ら ${ }^{1)}$ は単一刃先のビットを用いて衝撃貫入と静的貫 入試験を行い, 衝撃貫入抵抗の方が静的貫入抵抗より大きい $(1.2$ 倍）と報告している。この結果と本実験結果を単純に比較するこ との是非は不明であるが，この基礎試験結果については念頭に置 くべきものと考えている。

Fig.11 13 に示したロータリ・パーカッション掘削の比エネ ルギーは $P_{\text {in }}$ が増大, 寸なわち打撃エネルギーが増大すると, や

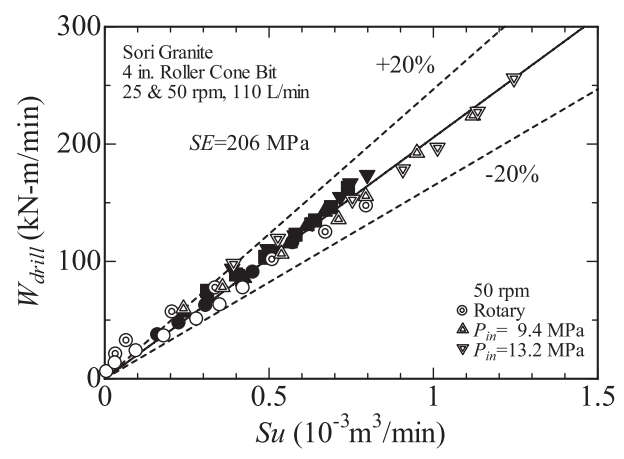

Fig.14 Relationship between rock volume drilled per minute $S u$ and drilling energy per minute $W_{\text {drill }}$ for Sori granite.

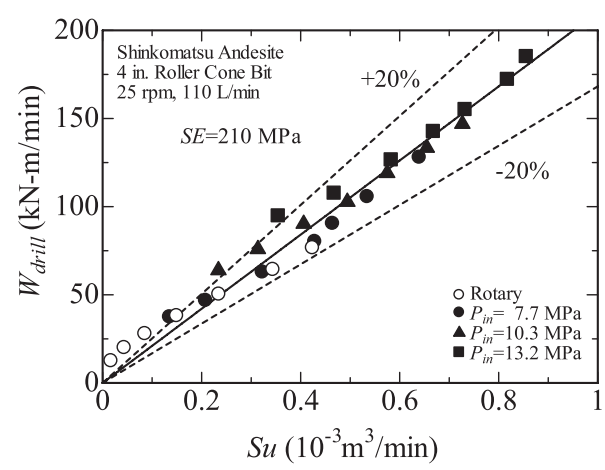

Fig.15 Relationship between $S u$ and $W_{\text {drill }}$ for Shinkomatsu andesite.

や大きくなる傾向が認められる。(5) 式からわかるように, この 傾向は打撃エネルギーの増大に見合って掘削速度が増大していな いことに起因していると考えられる。現在のところこの原因につ いては明確に説明できないが，掘屑の目視から本掘削法では掘屑 の再破砕が生じていると推定され，再破砕に伴うエネルギー損失 が一因として考えられる。ただし，打撃エネルギーの増大に伴う 比エネルギーの増大は比較的小さく, 本実験から得られた上記結 論を否定するものでない。

上記のローラコーンビットを用いたロータリ・パーカッション 掘削において, ビット荷重による比エネルギーの変化が小さいと いう知見を得たことは特筆できるかもしれない。その理由として, 後述のようにこの知見はパーカッション掘削機の設計を簡便化さ せる可能性があることが挙げられる。ただし, このような研究結 果の報告例は見当らないため, 本結果が広く成り立っているかど うかについては今後十分な検証が必要である。

$5 \cdot 2 \cdot 3$ 掘削体積と掘削エネルギーとの関係 前記のよ うに, 現在のところパーカッション掘削機の設計などに必要と考 えられる基礎データが不足している。基礎データの有無は, 特に 設計の初期段階 (概念・基本設計など ) では設計の適否を左右さ せる可能性が高い。このため, 大雑把ではあるが設計の初期段階 において有用であると考えられるデータの整理法の一つとして, 一分間当りの岩石掘削体積 $S u$ と一分間当りの掘削エネルギー $W_{\text {drill }}$ との関係を求めた。沢入花崗岩, 新小松安山岩および三城 目安山岩における両者の関係を，それぞれ Fig. 14, Fig. 15 およ び Fig. 16 に示す。沢入花崗岩の場合 (Fig. 14) はビット回転数が $25 \mathrm{rpm}$ と $50 \mathrm{rpm}$ のデータをプロットしてある (25rpm のデータの 凡例は Fig. 10 と同じである)。各図中の実線は, すべてのデータ を用いて原点を通る直線近似により求めた。直線の傾きは比エネ ルギー SE を表しており, 沢入花崗岩が $206 \mathrm{MPa}$ (相関係数 0.991), 新小松安山岩が $210 \mathrm{MPa}$ (同 0.986), 三城目安山岩が $105 \mathrm{MPa}$ (同 


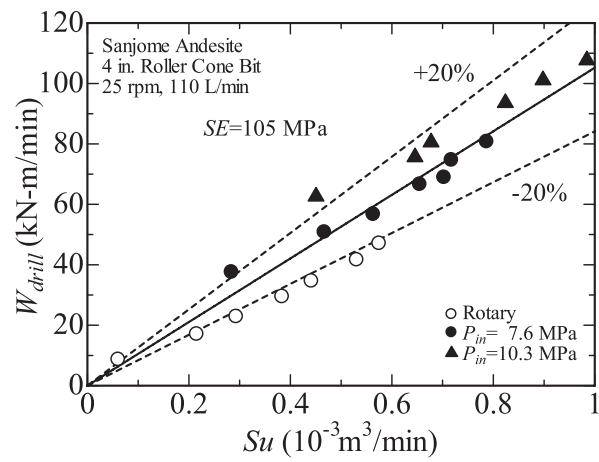

Fig.16 Relationship between $S u$ and $W_{\text {drill }}$ for Sanjome andesite.

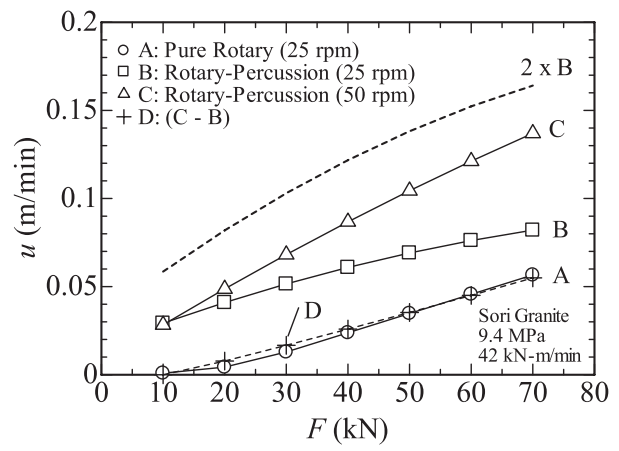

Fig.17 Composition of rotary and percussion drilling in rotary-percussion drilling ( $u-F$ plot).

0.948）となっている。つまり, これらの数值は大雑把には各岩石 の一軸圧縮強度 $S_{c}$ と一致していると見ることができる。すなわち,

$$
W_{\text {drill }}=S E \times 10^{3} \times S u \approx S_{c} \times 10^{3} \times S u
$$

パーカッション掘削機の設計に必要な基礎データを実規模の掘 削実験から求めることも考えられるものの, この方法は少なくと も設計の初期の段階では現実的でないことも十分考えられる。(6) 式からわかるように, Fig.14 などに示した $W_{\text {drill }} S u$ プロットにお いてビット断面積 (= 掘削孔断面積 $S$ ), 掘削速度 $u$ および岩石の 一軸圧縮強度 $S_{c}$ を想定すれば，大雑把ではあるがロータリ・パー カッション掘削に要するエネルギー $W_{\text {drill }}$ が推定できる (前記の ように Su が小さい範囲のロータリ掘削の比エネルギーはかなり 大きいことには注意を要する)。ただし, この $W_{\text {drill }}$ の構成 (具 体的には (4) 式の $\left.F u, 2 \pi N T, W_{\text {out }}\right)$ などについては不明の点も多く, 実験データがない限りパーカッション機構の出力などの設計は困 難であると思われる。本論文のみでこのような課題をすべて解決 することはできないが，以下に本掘削法を理解する上で最も重要 な情報であると考えられるロータリ掘削とパーカッション掘削の 構成に関して考察を行う。

$5 \cdot 2 \cdot 4$ ロータリ・パーカッション掘削に関わる考察

Fig. 17 は，掘削速度 $u$ について上記構成を調べるために作成し たものである (図中の $\mathrm{A}, \mathrm{B}, \mathrm{C}$ は沢入花崗岩の掘削実験から得 られたデータを近似して求めた)。ここで，A はビット回転数 $25 \mathrm{rpm}$ でロータリ掘削したとき，B と C はそれぞれ回転数 $25 \mathrm{rpm}$ と $50 \mathrm{rpm}$ でロータリ・パーカッション掘削したときの $F$ と $u$ と の関係である。なお, $\mathrm{B}$ と $\mathrm{C}$ は, 入口油压 $P_{i n}$ が $9.4 \mathrm{MPa}$, 一分 間当りの打撃エネルギー $W_{\text {out }}$ が約 $42 \mathrm{kN} \cdot \mathrm{m} / \mathrm{min}$ 一定の条件で得 られたものである。 D は C から B を差し引いて求めた。

打撃エネルギーがほぼ等しい $\mathrm{B}$ と C においてパーカッション

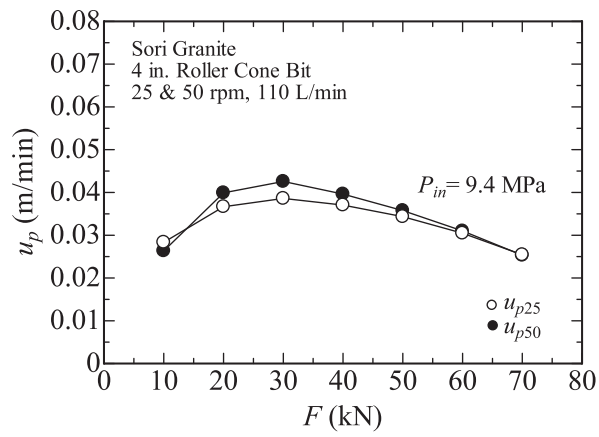

Fig.18 Effect of rotary speed on penetration rate of percussion drilling $u_{p}$.

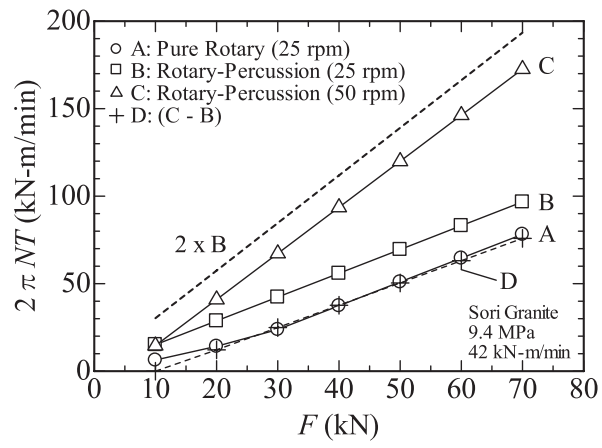

Fig.19 Composition of rotary and percussion drilling in rotary-percussion drilling ( $2 \pi N T-F$ plot).

掘削で得られた掘削速度 $u$ が同じであると仮定すると，D はビッ 卜回転数の差 $(25 \mathrm{rpm})$ によって生じたロータリ掘削の速度 $u$ の増 分を表す。この増分は A のビット回転数が $25 \mathrm{rpm}$ のときのロー タリ掘削の速度に他ならないので, ロータリ・パーカッション掘 削を構成するロータリ掘削の速度はロータリ掘削の速度と概ね等 しく，かつ上記仮定もほぼ正しいことがわかる。

Fig. 17 の結果を基に, ロータリ・パーカッション掘削における パーカッション掘削の速度 $u$ ( $u_{p}$ と表す) を求めた (Fig. 18)。図 中, ビット回転数が $25 \mathrm{rpm}$ と $50 \mathrm{rpm} の u_{p}$ をそれぞれ $u_{p 25}$ と $u_{p 50}$ と表した。図から上記仮定がほぼ正しいことが再確認できる。一 方， $u_{p}$ はビット荷重 $F$ によって増減しており, ビット荷重が約 30kNにおいて $u_{p}$ が最大となっている。

Fig. 19 は, Fig. 17 に示したデータについて $F$ と $2 \pi N T$ との関 係を調べたものである $(2 \pi N T$ は一分間当りの回転方向のエネル ギーで, 回転エネルギーと略す)。A はビット回転数 $25 \mathrm{rpm}$ でロー タリ掘削したとき, B と C はそれぞれ回転数 $25 \mathrm{rpm}$ と 50rpm でロー タリ・パーカッション掘削したときのデータである。 D は C か ら B を差し引いて求めた。

ロータリ掘削の場合，回転エネルギー $2 \pi N T$ は岩石破壊におい て消費される主要なエネルギーであるが，パーカッション掘削で は打撃エネルギーがその機能を果たしている。したがって, パー カッション掘削における $2 \pi N T$ はビットの回転に要するエネル ギーを表していると考えられる。

$\mathrm{B}$ と C におけるパーカッション掘削の $2 \pi N T$ が等しいと仮定す ると, Fig. 17 に示した掘削速度 $u$ の場合と同様な説明によって, ロータリ・パーカッション掘削を構成するロータリ掘削の $2 \pi N T$ は, 通常のロータリ掘削の $2 \pi N T$ と概袮しいという結果を導き 出すことができる。したがって，上記の仮定もほぼ正しいことが わかる。なお, 上記のパーカッション掘削における $2 \pi N T$ は $\mathrm{B}$ か 
ら A を差し引くことによって推定できる。この值として, ビッ 卜荷重が $30 〜 70 \mathrm{kN}$ において約 $18 \mathrm{kN} \cdot \mathrm{m} / \mathrm{min}$ を得た。

Fig.17〜19 に示した結果は $P_{\text {in }}$ が $9.4 \mathrm{MPa}\left(W_{\text {out }}\right.$ が約 $42 \mathrm{kN} \cdot \mathrm{m} /$ $\mathrm{min})$ の場合であるが， $P_{\text {in }}$ が $13.2 \mathrm{MPa}\left(W_{\text {out }}\right.$ が約 $\left.79 \mathrm{kN} \cdot \mathrm{m} / \mathrm{min}\right)$ の 結果も同様な傾向を示した。

本考察において得られた最も重要であると考えられる知見は, 少なくとも沢入花崗岩の実験範囲内ではロータリ・パーカッショ ン掘削を構成するロータリ掘削の成分 ( 掘削速度や回転エネル ギー) が通常のロータリ掘削の成分と概ね等しいという推定結果 である。この結果が広く成立していれば，上記考察からわかるよ うに掘削速度や一分間当りの掘削エネルギー $W_{\text {drill }}$ をロータリと パーカッション掘削の成分に大別できるようになり，パーカッ ション掘削機の設計などに有効であることは明らかである (ロー タリ掘削のデータは実験で収集しや寸く，かつ参考となるデータ も既存する)。ただし，この推定結果を得るのに用いたデータ数 は少ないため, 他の岩種も含めて多くのデータによる確認が必要 であると考えている。

\section{6.おわりに}

パーカッション掘削における岩石の掘削特性に関しては不明の 点も多く, また，パーカッション掘削機の設計などを行うのに必 要な基礎データも極めて少ない状況である。そこで, 本研究では ローラコーンビットを用いて硬質な花崗岩と安山岩および中硬質 の安山岩に対してロータリ掘削とロータリ・パーカッション掘削
を行い, 主として掘削エネルギーの観点から各岩石の掘削特性を 評価した。主な研究結果は以下のようにまとめられる。

(1) ロータリ掘削とロータリ・パーカッション掘削の比エネルギー の最小值は, 掘削した岩石の一軸圧縮強度と大雑把に一致した。

(2) 特に硬岩の場合, ビット荷重に伴うロータリ・パーカッショ ン掘削の比エネルギーの変化は, ロータリ掘削に比べてかな り小さかった。

(3) 花崗岩をロータリ・パーカッション掘削したときのロータリ 掘削の成分 ( 掘削速度と回転エネルギー) について検討したと ころ, これらの成分は通常のロータリ掘削の成分と概袘し いという推定結果を得た。

今後ともパーカッション掘削に関わる研究を継続し，本論文に おいて残されたいくつかの課題を解決したいと考えている。

\section{References}

1) S. Okubo, Y. Nishimatsu, M. Akiyama and T. Tatsumi: Journal of MMIJ, 108 (1992), 134-140.

2) S. Okubo and Y. Nishimatsu: Journal of MMIJ, 107 (1991), 209-214.

3) R. Teale: Int. J. Rock Mech. Mining Sci., 2 (1965) , 57-73.

4) R.P. Vincent and L.B. Wilder: Oil \& Gas Journal, 67, No.13 (1969), 74-78.

5) D.S. Pixton and D.R. Hall: Geothermal Resources Council Bulletin, 24 (1995), 249-252.

6) H. Karasawa, A. Ota, H. Abe, M. Koizumi, M. Suda and N. Yamada: Proc. MMIJ Fal Meeting (2006), Vol.AB, pp.63-66.

7) H. Karasawa, T. Yokota, M. Koizumi and A. Ota: MMIJ Annual Meeting (2005), Vol. I pp.103-104.

8) S. Okubo, A. Ota and K. Fukui: Journal of MMIJ, 111 (1995) , 301-308.

9) L.L. Hoberock and G.J. Bratcher: Journal of Energy Resources Technology, 118 (1996), 249-255. 